\title{
First cytogenetic information for five Nilotic elephantfishes and a problem of ancestral karyotype of the family Mormyridae (Osteoglossiformes)
}

\author{
Sergey Simanovsky', Dmitry Medvedev', Fekadu Tefera², Alexander Golubtsov' \\ I Severtsov Institute of Ecology and Evolution, Russian Academy of Sciences, 33 Leninskij prosp., Moscow, \\ 119071, Russia 2 National Fishery and Aquatic Life Research Center, Ethiopian Institute of Agricultural \\ Research, Sebeta, P.O. Box 64, Ethiopia
}

Corresponding author: Sergey Simanovsky (sergey.a.simanovsky@gmail.com)

Academic editor: Alicja Boroń | Received 7 April 2020 | Accepted 23 July 2020 | Published 19 August 2020

http://zoobank.org/56F3905D-E628-4D37-A60D-4D419EFOC37A

Citation: Simanovsky S, Medvedev D, Tefera F, Golubtsov A (2020) First cytogenetic information for five Nilotic elephantfishes and a problem of ancestral karyotype of the family Mormyridae (Osteoglossiformes). Comparative Cytogenetics 14(3): 387-397. https://doi.org/10.3897/CompCytogen.v14i3.52727

\begin{abstract}
The elephantfish family Mormyridae is the most diverse lineage of the primitive teleostean clade Osteoglossomorpha distributed in inland waters of all continents except Antarctica and Europe. The family Mormyridae is endemic to Africa and includes 22 genera and almost 230 species. The evolutionary radiation of mormyrids most probably should be attributed to their capability of both generating and receiving weak electric signals. Up-to-date cytogenetic studies have revealed substantial karyotype differentiation among the nine investigated elephantfish species and genera (a single species studied per each genus). In the present study, karyotypes of five species representing five mormyrid genera (four unexplored ones) collected from the White Nile system in southwestern Ethiopia are described for the first time. The results show substantial variety of the diploid chromosome and fundamental numbers: $2 \mathrm{n}=48$ and $\mathrm{FN}=54$ in Brevimyrus niger (Günther, 1866), 2n = 50 and $\mathrm{FN}=72$ in Cyphomyrus petherici (Boulenger, 1898), $2 \mathrm{n}=50$ and FN = 78 in Hippopotamyrus pictus (Marcusen, 1864), 2n = 50 and FN = 76 in Marcusenius cyprinoides (Linnaeus, 1758), $2 \mathrm{n}=52$ and FN = 52 in Mormyrops anguilloides (Linnaeus, 1758). Karyotype structure in the latter species seems to be close to the ancestral condition for the family. This hypothesis is discussed in the light of available data on karyotype diversity and phylogeny of mormyrids.
\end{abstract}

\section{Keywords}

Africa, chromosomes, karyotype evolution, Brevimyrus, Cyphomyrus, Hippopotamyrus, Marcusenius, Mormyrops

Copyright Sergey Simanovsky et al. This is an open access article distributed under the terms of the Creative Commons Attribution License (CC BY 4.0), which permits unrestricted use, distribution, and reproduction in any medium, provided the original author and source are credited. 


\section{Introduction}

The elephantfish family Mormyridae belongs to one of the most primitive groups of teleostean fishes, the cohort Osteoglossomorpha (Nelson et al. 2016). The family is endemic to the African continent and includes 22 genera and almost 230 species (Froese and Pauly 2019; Eschmeyer et al. 2020). In genus and species diversity it exceeds all other extant osteoglossomorph lineages. The evolutionary radiation of mormyrids most probably should be attributed to their ability of both generating and receiving weak electric signals that provides dual functions of 'electrolocation' and communication (Hopkins 2009, Carlson and Arnegard 2011).

First cytogenetic data on the osteoglossomorphs and particularly mormyrids were published by Hinegardner and Rosen (1972) and Uyeno (1973) almost half a century ago. Thereafter, the karyotype structure and cellular DNA content of osteoglossomorphs were progressively studied (reviewed by Arai 2011; Canitz et al. 2016; Barby et al. 2018; Cioffi et al. 2019). The recent works on mormyrids (Krysanov and Golubtsov 2014; Ozouf-Costaz et al. 2015; Canitz et al. 2016) raised to nine the number of mormyrid genera studied. The number of species studied is also nine because one species only has been karyotyped for all genera. The diploid chromosome numbers in most mormyrids are similar $(2 \mathrm{n}=48$ or 50 excepting Pollimyrus Taverne, 1971 with $2 \mathrm{n}=40)$. Nevertheless, the varying bi-armed chromosome numbers and 'amazing' diversity in NOR positions and C-banding patterns provide evidence for the substantial divergence in the karyotype structure with the dominating role of pericentric inversions (Ozouf-Costaz et al. 2015).

There is a coherent hypothesis about phylogenetic position of the family Mormyridae among other Osteoglossomorpha (Lavoué and Sullivan 2004; Inoue et al. 2009; Nelson et al. 2016). The phylogenetic structure of mormyrids themselves is not well-elaborated, but three basal groups in their radiation (the genera Petrocephalus Marcusen, 1854; Myomyrus Boulenger, 1898; Mormyrops Müller, 1843) are reliably defined (Alves-Gomes and Hopkins 1997; Sullivan et al. 2000; Lavoué et al. 2003). This makes it possible to hypothesize about the mormyrid karyotype evolution. Based on available data Canitz et al. (2016) suggested for Mormyridae the ancestral chromosome number $2 n=48-50$, that is well-coordinated with the hypothetical ancestral karyotype for the teleostean fishes and early vertebrates in general (Ohno et al. 1969; Jaillon et al. 2004; Kohn et al. 2006; Nakatani et al. 2007).

Meanwhile, only a small fraction of the total mormyrid diversity (less than 5\% of species) has been yet studied cytogenetically. New findings may correct the existing views on their karyotype evolution. In the present study, new data for five mormyrid species from northern East Africa are presented using cytogenetic analysis (chromosome number and morphology). Relevance of these data to undrstanding of karyotype evolution within the family Mormyridae is considered.

\section{Material and methods}

The fifteen individuals studied represent five species of different genera - Brevimyrus niger (Günther, 1866), Cyphomyrus petherici (Boulenger, 1898), Hippopotamyrus pic- 
tus (Marcusen, 1864), Marcusenius cyprinoides (Linnaeus, 1758) and Mormyrops anguilloides (Linnaeus, 1758) - of the elephantfish family Mormyridae (Table 1). Fish were collected in southwestern Ethiopia under the umbrella of the Joint EthiopianRussian Biological Expedition (JERBE) at three sites in November of 2017: the Baro River downstream of the City of Itang $\left(8^{\circ} 10^{\prime} 47^{\prime \prime} \mathrm{N}, 34^{\circ} 15^{\prime} 2^{\prime \prime} \mathrm{E}\right)$, the Tida River half way between the cities of Gambela and Itang $\left(8^{\circ} 16^{\prime} 15^{\prime \prime} \mathrm{N}, 34^{\circ} 25^{\prime} 52^{\prime \prime} \mathrm{E}\right)$ and the Al-

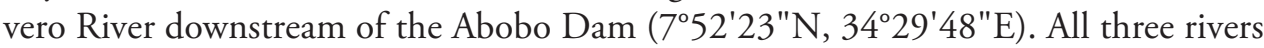
belong to the Sobat River drainage discharging into the White Nile in South Sudan. Fish were caught with cast or gill nets, delivered in 80-1 plastic containers into the field laboratory, where they were kept in permamently aerated water for several hours before treatment.

Before preparation fish were treated intraperitoneally with $0.1 \%$ colchicine for 3-4 hours. Then fish were euthanized with an overdose of tricaine methanesulfonate (MS-222), identified based on morphological key characters (Golubtsov et al. 1995, Levin and Golubtsov 2018), measured to an accuracy of $1 \mathrm{~mm}$, dissected for gonad examination and tissue sampling, and preserved in 10\% formaldehyde. Vouchers are deposited at the Institute of Ecology and Evolution (Moscow) under provisional labels of JERBE.

Chromosome preparations were obtained from anterior kidney according to Kligerman and Bloom (1977). Briefly, the anterior kidney tissue was incubated with $0.075 \mathrm{M} \mathrm{KCl}$ hypotonic solution for 20-30 min at room temperature and fixed with 3:1 methanol : acetic acid. To prepare slides a fixed tissue was incubated with 50\% glacial acetic acid, suspended, and dropped onto a hot slides. Air-dried chromosome spreads were stained conventionally with $4 \%$ Giemsa solution in phosphate buffer at $\mathrm{pH} 6.8$ for $8 \mathrm{~min}$.

Chromosome spreads were analysed under "Axioplan 2 Imaging" microscope (Carl Zeiss, Germany) equipped with "CV-M4+CL" camera (JAI, Japan) and "Ikaros" software (MetaSystems, Germany). Karyotypes were established according to the centromere position following the nomenclature of Levan et al. (1964). Chromosomes were classified as metacentric (a), submetacentric ( $\mathrm{sm}$ ) and acrocentric (a), including subtelocentric and telocentric chromosomes, and grouped according to their morphology in order of decreasing size. To determine the fundamental number $(\mathrm{FN})$, metacentrics and submetacentrics were considered bi-armed and acrocentrics as uni-armed. The number of complete metaphase plates studied for each specimen is presented in Table 1.

Table I. Species, fish standard length (SL), numbers of individuals $(\mathrm{N})$ and metaphases $\left(\mathrm{N}_{\mathrm{m}}\right)$ studied, and collection site.

\begin{tabular}{|c|c|c|c|c|}
\hline Species & SL, mm & $\mathbf{N}$ & $\mathbf{N}_{\mathrm{mt}}$ & Collection site \\
\hline Brevimyrus niger & $81-87$ & $3(1+9,2 \widehat{\jmath})$ & 32 & Tida River \\
\hline Cyphomyrus petherici & $69-153$ & $5(3+, 2 \hat{\jmath})$ & 54 & \multirow[t]{4}{*}{ Alvero River } \\
\hline Hippopotamyrus pictus & 197 & $1\left(ठ^{\Uparrow}\right)$ & 11 & \\
\hline Marcusenius cyprinoides & $196-217$ & $3\left(2+, 1 \delta^{\lambda}\right)$ & 30 & \\
\hline \multirow[t]{2}{*}{ Mormyrops anguilloides } & $409-498$ & $2\left(1+, 1{ }^{\curvearrowright}\right)$ & 21 & \\
\hline & 413 & $1(q)$ & 17 & Baro River \\
\hline
\end{tabular}



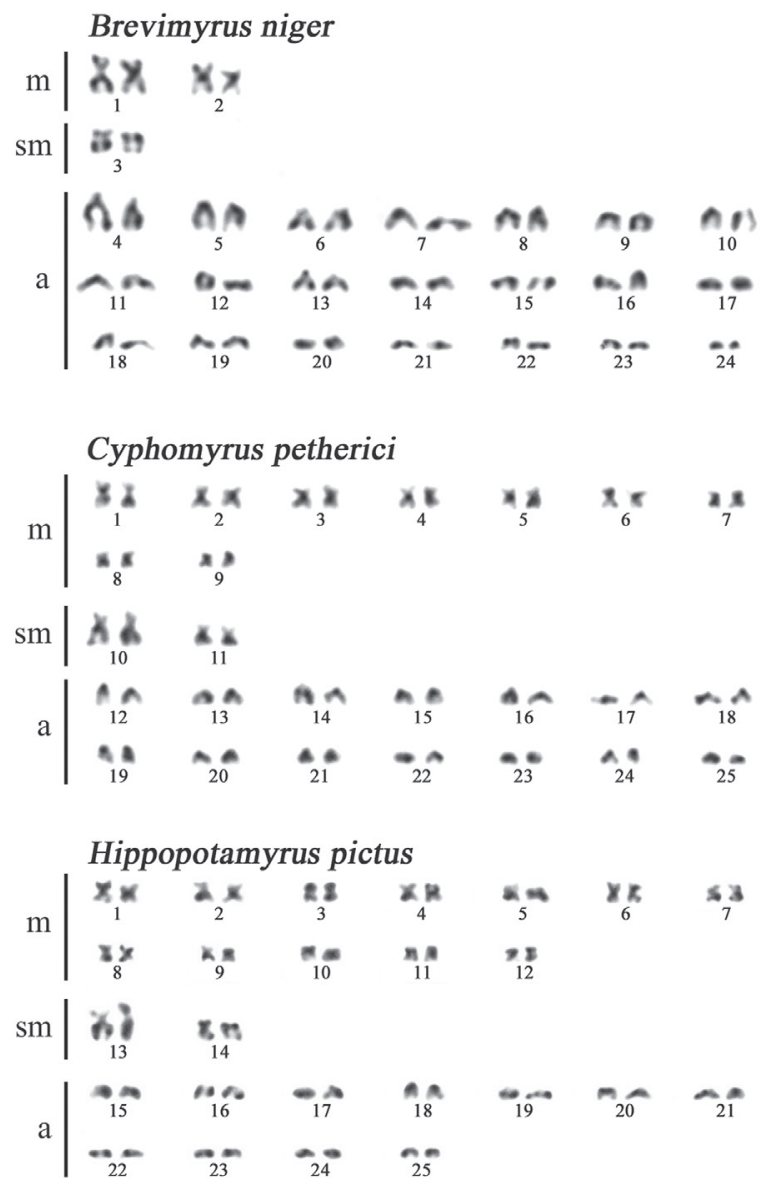

Marcusenius cyprinoides

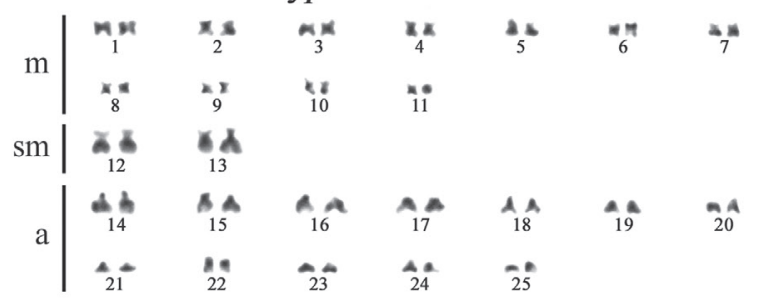

Mormyrops anguilloides

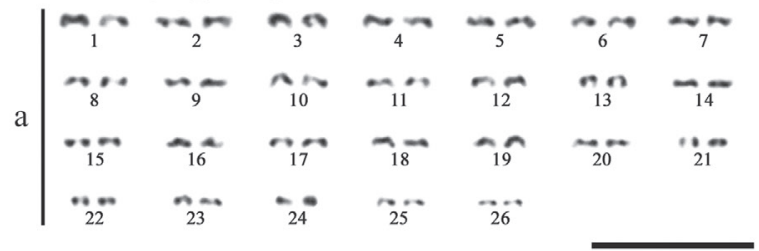

Figure I. Karyotypes of five elephantfishes of the family Mormyridae. Scale bar: $10 \mu \mathrm{m}$. 


\section{Results and discussion}

Brevimyrus niger has a karyotype with $2 \mathrm{n}=48$ (Fig. 1) consisting of 4 metacentrics (m), 2 submetacentrics ( $\mathrm{sm}$ ) and 42 acrocentrics (a). Three taxa share the same diploid numbers of chromosomes $2 \mathrm{n}=50$ but differ in karyotypic formula: Cyphomyrus petherici has $18 \mathrm{~m}$, $4 \mathrm{sm}$ and 28a, Hippopotamyrus pictus has 24m, 4sm and 22a, and Marcusenius cyprinoides has $22 \mathrm{~m}, 4 \mathrm{sm}$ and 24a. Finally, Mormyrops anguilloides has karyotype with $2 \mathrm{n}=52$ consisting exclusively of acrocentrics gradually decreasing in size. In the other species studied by us one or two pairs of metacentrics or submetacentrics noticeably exceed in size most acrocentrics that admits an origin of the larger chromosomes via the centric fusions.

No distinguishable sex chromosomes were observed in complements of the four species in which individuals of both sexes were studied (B. niger, C. petherici, M. cyprinoides, and $M$. anguilloides), while the only male of $H$. pictus was karyotyped (Table 1). This is in agreement with the lack of reports on sex chromosomes in other mormyrids, but presence of heteromorphic sex chromosomes was supposed in the Asian arowana Scleropages formosus (Müller \& Schlegel, 1840) from the family Osteoglossidae distantly related to Mormyridae (Bian et al. 2016; but see Cioffi et al. 2019).

Data for all mormyrid taxa studied cytogenetically in the present study and earlier are presented in Table 2 . Taxa within the subfamily Mormyrinae are listed in alphabetical order. Recognition of the subfamily Petrocephalinae, as a sister group to all other mormyrids, is well-grounded by morphological (including structure of electrocytes) and molecular phylogenetic data (Taverne 1972; Alves-Gomes and Hopkins 1997; Sullivan et al. 2000; Lavoué et al. 2003). For the two earlier studied taxa names are changed in accordance with recent taxonomic arrangements (Eschmeyer et al. 2020): Brienomyrus brachyistius (Gill, 1862) was reported as "Marcusenius brachistius Gill" by Uyeno (1973) and Campylomormyrus rhynchophorus (Boulenger, 1898) as C. compressirostris (Pellegrin, 1924) by Canitz et al. (2016). Brienomyrus sp.7 of Ozouf-Costaz et al. (2015) is listed as Paramormyrops sp.7 following to Ráb et al. (2016).

Brevimyrus niger shares the karyotype with $2 \mathrm{n}=48$ with three other mormyrid taxa, but differs from two of them - Campylomormyrus rhynchophorus with FN $=78$ and Gnathonemus petersii (Günther 1862) with $\mathrm{FN}=64$ or 68 - by a smaller number of biarmed elements $(\mathrm{FN}=54)$. For third taxon, Brienomyrus brachyistius, the unbalanced karyotype with FN = 53 was described in a single specimen (Uyeno 1973). Apart from the unpaired metacentric chromosome of the unclear nature, its karyotype looks similar to that of Brevimyrus niger. Both species have two pairs of large biarmed chromosomes, while a pair of uni-armed chromosomes in Brienomyrus brachyistius might be substituted by a pair of submetacentrics in Brevimyrus niger lineage.

The karyotype with $2 \mathrm{n}=50$ was found to be dominating in both presently and previously studied mormyrids (three and five taxa, respectively). Cyphomyrus petherici (FN = 72), Hippopotamyrus pictus ( $\mathrm{FN}=78$ ) and Marcusenius cyprinoides $(\mathrm{FN}=76$ ) have more biarmed elements in their compliment than any other mormyrid studied except Campylomormyrus rhynchophorus (FN = 78). Congeneric Marcusenius cyprinoides and M. moorii (Günther, 1867) sharing the same chromosome number differ substantially in 
their karyotype structure. Up to recently Cyphomyrus petherici was considered as belonging to the genus Pollimyrus (Taverne 1971; Moritz et al. 2019). Substantial cytogenetic dissimilarity between the single studied species of the latter genus $(2 \mathrm{n}=40, \mathrm{FN}=42)$ and C. petherici corroborates the change of its generic position (Levin and Golubtsov 2018).

Mormyrops anguilloides has a karyotype unique for the mormyrids studied and composed of 52 uni-armed chromosomes. There are two mormyrids - Petrocephalus microphthalmus Pellegrin, 1909 and Stomatorhinus walkeri (Günther, 1867) - with 2n $=50$ and $\mathrm{FN}=52$. Karyotypes of these three taxa dominated by the uni-armed elements seem to be close to each other and to a hypothetical ancestral karyotype of the family Mormyridae. Mutial trasnformation of these karyotypes could occur in a few evolutionary steps (Fig. 2). It is important that two of the three genera under consideration (Petrocephalus and Mormyrops) appear to be well-defined basal groups in the family phylogeny (Sullivan et al. 2000; Lavoué et al. 2003). Phylogenetic position of the third genera (Stomatorhinus) is unclear. Though it appears in the rather basal position (next to Petrocephalus) in the small cladogram by Ozouf-Costaz et al. (2015) based of the mitochondrial cytochrome $b$ sequences, in the more extensive mormyrid phylogenies this genus is nested deeper in the phylogenetic trees but in varying and poorly surported positions (Lavoué et al. 2003; Sullivan et al. 2016; Levin and Golubtsov 2018). Unfortunatelly, cytogenetic data for one more genus with the well-defined basal position in the mormyrid phylogeny (Myomyrus, stemming out between Petrocephalus and Mormyrops) are absent.

Based on the simultaneous phylogenetic analysis of molecular data and chromosome number, Canitz et al. (2016) recognized karyotype with $n=24$ as the most parsimonius ancestral state for the order Osteoglossiformes, while the haploid chromosome number of $\mathrm{n}=24-25$ was inferred for the most recent common ancestor of the family Mormyridae. Their analysis, however, did not include the most recent cytogenetic data for several osteoglossomorph clades (Ráb et al. 2016; Barby et al. 2018; Hatanaka et al. 2018; Jegede et al. 2018; Cioffi et al. 2019; de Oliveira et al. 2019). Moreover, the recent genomic data evidence for the ancestral Euteleostomi karyotype of 50 chromosomes with domination by acrocentric elements (Nakatani et al. 2007; Sacerdot et al. 2018; de Oliveira et al. 2019). If the ancestral karyotype of Mormyridae contained 50 uni-armed elements, three chromosomal rearrangements only might produce the observed karyotype structure in the three mormyrid genera (Petrocephalus, Stomatorhinus and Mormyrops) tentatively recognized by us as the least cytogenetically advanced (Fig. 2). The solitary submetacentic pairs in Petrocephalus and Stomatorhinus are suggested to be not syntenic because of some differences in chromosome morphology (Ozouf-Costaz et al. 2015). If the ancestral karyotype of Mormyridae contained 50 uni-armed elements, it is apparently not retained by any extant mormyrid or osteoglossomorph, in general. Although the karyotype with $2 \mathrm{n}=50$ is dominating among mormyrids, it contains from 1 to 14 pairs of bi-armed elements (Table 2).

Based on available data the most parsimonius scenarios of the early karyptype evolution in Mormyridae are presented in Figure 2. Three different ancestral karyotypes are considered: $2 \mathrm{n}=50$ and $\mathrm{FN}=50$ (no bi-armed elements), $2 \mathrm{n}=50$ and $\mathrm{FN}=52$ (the only pair of bi-armed elements), $2 \mathrm{n}=52$ and $\mathrm{FN}=52$ (no bi-armed elements). The 

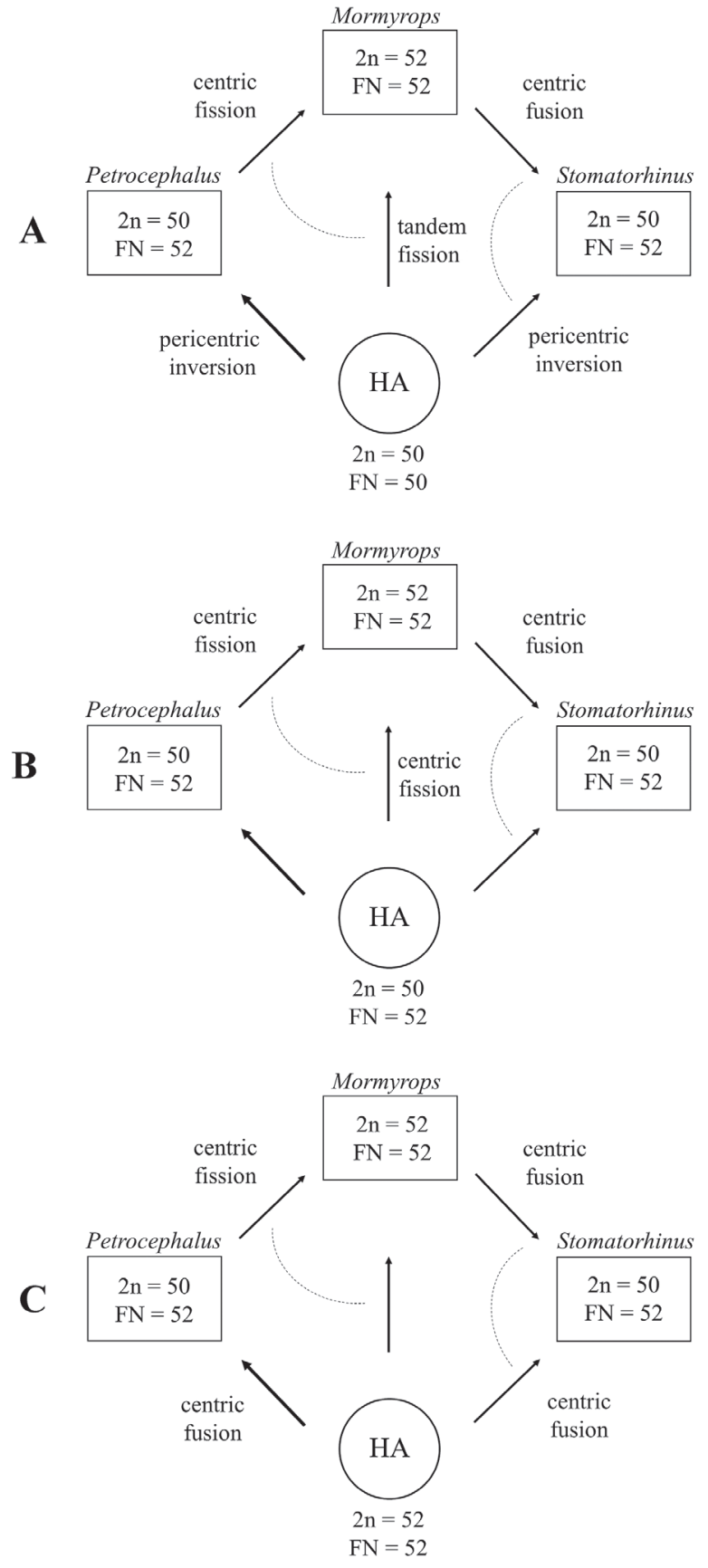

Figure 2. Most parsimonious scenarios of the early karyotype evolution within the family Mormyridae including three variants (A-C) of karyotype structure in a hypothetic ancestor (HA) and three studied lineages (the genera Petrocephalus, Stomatorhinus and Mormyrops) with least advanced karyotype structure within the family. The alternative transformations of karyotype structure are joint with a dashed line. The solitary submetacentric pairs in Petrocephalus and Stomatorhinus are suggested to be not syntenic. 
Table 2. Cytogenetically studied elephantfishes of the family Mormyridae. Diploid chromosome number (2n), karyotypic formula, fundamental number $(\mathrm{FN})$ and geographic origin.

\begin{tabular}{|c|c|c|c|c|c|}
\hline Taxon & $2 n$ & $\begin{array}{c}\text { Karyotypic } \\
\text { formula }\end{array}$ & FN & Origin & References \\
\hline \multicolumn{6}{|l|}{ Subfamily Petrocephalinae } \\
\hline Petrocephalus microphthalmus Pellegrin, 1909 & 50 & $2 s m+48 a$ & 52 & Ogooué Basin, Gabon & $\begin{array}{c}\text { Ozouf-Costaz et } \\
\text { al. } 2015\end{array}$ \\
\hline \multicolumn{6}{|l|}{ Subfamily Mormyrinae } \\
\hline Brevimyrus niger (Günther, 1866) & 48 & $4 m+2 s m+42 a$ & 54 & $\begin{array}{l}\text { White Nile Basin, } \\
\text { Ethiopia }\end{array}$ & This study \\
\hline Brienomyrus brachyistius (Gill, 1862) & 48 & $\begin{aligned} 1 m+ & 4 s m+2 s t \\
+ & 41 a\end{aligned}$ & 53 & Unknown (fish store) & Uyeno 1973 \\
\hline Campylomormyrus rhynchophorus (Boulenger, 1898) & 48 & $26 m+4 s m+18 a$ & 78 & $\begin{array}{l}\text { Unknown (laboratory } \\
\text { stock) }\end{array}$ & Canitz et al. 2016 \\
\hline Cyphomyrus petherici (Boulenger, 1898) & 50 & $18 m+4 s m+28 a$ & 72 & $\begin{array}{c}\text { White Nile Basin, } \\
\text { Ethiopia }\end{array}$ & This study \\
\hline \multirow[t]{2}{*}{ Gnathonemus petersii (Günther, 1862) } & 48 & $10 m+6 s m+32 a$ & 64 & Unknown (fish store) & Uyeno 1973 \\
\hline & 48 & $18 m+2 s m+28 a$ & 68 & Unknown (fish store) & $\begin{array}{c}\text { Ozouf-Costaz et } \\
\text { al. } 2015\end{array}$ \\
\hline Hippopotamyrus pictus (Marcusen, 1864) & 50 & $24 m+4 s m+22 a$ & 78 & $\begin{array}{c}\text { White Nile Basin, } \\
\text { Ethiopia }\end{array}$ & This study \\
\hline Ivindomyrus opdenboschi Taverne et Géry, 1975 & 50 & $10 m+2 s m+38 a$ & 62 & Ntem River, Gabon & $\begin{array}{c}\text { Ozouf-Costaz et } \\
\text { al. } 2015\end{array}$ \\
\hline Marcusenius cyprinoides (Linnaeus, 1758) & 50 & $22 m+4 s m+24 a$ & 76 & $\begin{array}{c}\text { White Nile Basin, } \\
\text { Ethiopia }\end{array}$ & This study \\
\hline Marcusenius moorii (Günther, 1867) & 50 & $4 s m+46 a$ & 54 & Ntem River, Gabon & $\begin{array}{c}\text { Ozouf-Costaz et } \\
\text { al. } 2015\end{array}$ \\
\hline Mormyrops anguilloides (Linnaeus, 1758) & 52 & $52 a$ & 52 & $\begin{array}{c}\text { White Nile Basin, } \\
\text { Ethiopia }\end{array}$ & This study \\
\hline Paramormyrops sp.7 & 50 & $2 m+6 s m+42 a$ & 58 & $\begin{array}{c}\text { Ebeigne, Woleu River, } \\
\text { Gabon }\end{array}$ & $\begin{array}{l}\text { Ozouf-Costaz et } \\
\text { al. } 2015\end{array}$ \\
\hline Pollimyrus prope nigricans (Boulenger, 1906) & 40 & $2 m+38 a$ & 42 & $\begin{array}{l}\text { White Nile and Omo- } \\
\text { Turkana basins, Ethiopia }\end{array}$ & $\begin{array}{c}\text { Krysanov and } \\
\text { Golubtsov } 2014\end{array}$ \\
\hline Stomatorhinus walkeri (Günther, 1867) & 50 & $2 s m+48 a$ & 52 & Ogooué Basin, Gabon & $\begin{array}{c}\text { Ozouf-Costaz et } \\
\text { al. } 2015\end{array}$ \\
\hline
\end{tabular}

karyotype structure suggested for a hypothetic ancestor could not be retained in any extant mormyrid lineage (Fig. 2A) or retained in Petrocephalus (Fig. 2B) or Mormyrops (Fig. 2C). It is impossible to judge which of the scenarios considered is more preferable. There are also plenty of less parsimonious scenarios that are not considered by us.

We believe that further cytogenetic studies of various mormyrid taxa may shape the existing views on the karyotype evolution within this diverse group of fish. Looking for the probable interspecific variation of the karyotype structure within the three phylogenetically basal groups (the genera Petrocephalus, Myomyrus, Mormyrops) is of special interest.

\section{Acknowledgments}

We gratefully acknowledge the JERBE coordinator Andrey A. Darkov (IEE RAS, Moscow) for logistic support, Sergey E. Cherenkov (IEE) for sharing field operations and assistance in collecting material, Eugeny Yu. Krysanov (IEE) for precious help at different stages of our work, Alicja Boroń (University of Warmia and Mazury in Olsztyn), Mikhail V. Mina (Koltsov Institute of Developmental Biology RAS, Moscow), Claudio Oliveira (São Paulo State University, São Paulo) for critical comments on the manu- 
script. This work is financially supported by the Russian Foundation for Basic Research Project no. 18-34-00638 for SS and benefits also (at the stage of manuscript preparation) from the Russian Science Foundation Project no. 19-14-00218 for AG.

\section{References}

Alves-Gomes J, Hopkins CD (1997) Molecular insights into the phylogeny of mormyriform fishes and the evolution of their electric organs. Brain, Behavior and Evolution 49: $324-$ 350. https://doi.org/10.1159/000113001

Arai R (2011) Fish karyotypes - a Check List. Springer, 340 pp. https://doi.org/10.1007/9784-431-53877-6

Barby FF, Ráb P, Lavoué S, Ezaz T, Bertollo LAC, Kilian A, Maruyama SR, de Oliveira EA, Artoni RF, Santos MH, Jegede OI, Hatanaka T, Tanomtong A, Liehr T, Cioffi MB (2018) From chromosomes to genome: insights into the evolutionary relationships and biogeography of Old World knifefishes (Notopteridae; Osteoglossiformes). Genes 96(6): 1-306. https://doi.org/10.3390/genes9060306

Bian C, Hu Y, Ravi V, Kuznetsova IS, Shen X, Mu X, Sun Y, You X, Li J, Li X, Qiu Y, Tay B-H, Thevasagayam NM, Komissarov AS, Trifonov V, Kabilov M, Tupikin A, Luo J, Liu Y, Song H, Liu C, Wang X, Gu D, Yang Y, Li W, Polgar G, Fan G, Zeng P, Zhang H, Xiong Z, Tang Z, Peng C, Ruan Z, Yu H, Chen J, Fan M, Huang Y, Wang M, Zhao X, Hu G, Yang H, Wang J, Wang J, Xu X, Song L, Xu G, Xu P, Xu J, O’Brien SJ, Orbán L, Venkatesh B, Shi Q (2016) The Asian arowana (Scleropages formosus) genome provides new insights into the evolution of an early lineage of teleosts. Scientific Reports 6: 1-17. https://doi.org/10.1038/srep24501

Canitz J, Kirschbaum F, Tiedemann R (2016) Karyotype description of the African weakly electric fish Campylomormyrus compressirostris in the context of chromosome evolution in Osteoglossiformes. Journal of Physiology-Paris 110: 273-280. https://doi.org/10.1016/j. jphysparis.2017.01.002

Carlson BA, Arnegard ME (2011) Neural innovations and the diversification of African weakly electric fishes. Communicative \& Integrative Biology 4(6): 720-725. https://doi. org/10.4161/cib.17483

Cioffi MB, Ráb P, Ezaz T, Bertollo LAC, Lavoué S, de Oliveira EA, Sember A, Molina WF, Santos de Souza FH, Majtánová Z, Liehr T, Al-Rikabi ABH, Yano CF, Viana P, Feldberg E, Unmack P, Hatanaka T, Tanomtong A, Perez MF (2019) Deciphering the evolutionary history of arowana fishes (Teleostei, Osteoglossiformes, Osteoglossidae): insight from comparative cytogenomics. International Journal of Molecular Sciences 20 (17): 1-19. [4296]. https://doi.org/10.3390/ijms20174296

de Oliveira EA, Bertollo LAC, Rab P, Ezaz T, Yano CF, Hatanaka T, Jegede OI, Tanomtong A, Liehr T, Sember A, Maruyama SR, Feldberg E, Viana PF, Cioffi MB (2019) Cytogenetics, genomics and biodiversity of the South American and African Arapaimidae fish family (Teleostei, Osteoglossiformes). PLoS ONE 14(3): e0214225. https://doi.org/10.1371/journal.pone.0214225

Eschmeyer WN, Fricke R, van der Laan R [Eds] (2020) Catalog of Fishes: Genera, Species, References. http://researcharchive.calacademy.org/research/ichthyology/catalog/fishcatmain. asp [Accesed 04.06.2020] 
Froese R, Pauly D (2019) FishBase. http://www.fishbase.org [accessed 04.06.2020]

Golubtsov AS, Darkov AA, Dgebuadze YY, Mina MV (1995) An artificial key to fish species of the Gambela region (the White Nile basin in the limits of Ethiopia). Joint Ethio-Russian Biological Expedition, Addis Abeba, 84 pp.

Hatanaka T, de Oliveira EA, Ráb P, Yano CF, Bertollo LAC, Ezaz T, Jegede OOI, Liehr T, Olaleye VF, Cioffi MB (2018) First chromosomal analysis in Gymnarchus niloticus (Gymnarchidae: Osteoglossiformes): insights into the karyotype evolution of this ancient fish order. Biological Journal of the Linnean Society 125: 83-92. https://doi.org/10.1093/biolinnean/bly098

Hinegardner R, Rosen DE (1972) Cellular DNA content and the evolution of teleostean fishes. American Naturalist 106: 621-644. https://doi.org/10.1086/282801

Hopkins CD (2009) Electrical perception and communication. In: Squire LR (Ed.) Encyclopedia of neuroscience, volume 3, Academic Press, Oxford, 813-831. https://doi. org/10.1016/B978-008045046-9.01827-1

Inoue JG, Kumazawa Y, Miya M, Nishida M (2009) The historical biogeography of the freshwater knifefishes using mitogenomic approaches: a Mesozoic origin of the Asian notopterids (Actinopterygii: Osteoglossomorpha). Molecular Phylogenetics and Evolution 51: 486-499. https://doi.org/10.1016/j.ympev.2009.01.020

Jaillon O, Aury J-M, Brunet F, Petit J-L, Stange-Thomann N, Mauceli E, Bouneau L, Fischer C, Ozouf-Costaz C, Bernot A, Nicaud S, Jaffe D, Fisher S, Lutfalla G, Dossat C, Segurens B, Dasilva C, Salanoubat M, Levy M, Boudet N, Castellano S, Anthouard V, Jubin C, Castelli V, Katinka M, Vacherie B, Biémont C, Skalli Z, Cattolico L, Poulain J, de Berardinis V, Cruaud C, Duprat S, Brottier P, Coutanceau J-P, Gouzy J, Parra G, Lardier G, Chapple C, McKernan KJ, McEwan P, Bosak S, Kellis M, Volff J-N, Guigó R, Zody MC, Mesirov J, Lindblad-Toh K, Birren B, Nusbaum C, Kahn D, Robinson-Rechavi M, Laudet V, Schachter V, Quétier F, Saurin W, Scarpelli C, Wincker P, Lander ES, Weissenbach JW, Crollius HR (2004) Genome duplication in the teleost fish Tetraodon nigroviridis reveals the early vertebrate protokaryotype. Nature 2004: 946-957. https://doi.org/10.1038/nature03025

Jegede O, Akintoye MA, Awopetu JI (2018) Karyotype of the African weakly electric fish, Gymnarchus niloticus (Osteoglossiformes: Gymnarchidae) from Oluwa River, Nigeria. Ife Journal of Science 20(3): 539-545. https://doi.org/10.4314/ijs.v20i3.8

Kohn M, Hogel J, Vogel W, Kehrer-Sawatzki H, Graves J, Hameister H (2006) Reconstruction of a 450-My-old ancestral vertebrate protokaryotype. Trends in Genetics 22: 203-210. https://doi.org/10.1016/j.tig.2006.02.008

Kligerman AD, Bloom SE (1977) Rapid chromosome preparations from solid tissues of fishes. Journal of the Fisheries Research Board of Canada 34(2): 266-269. https://doi. org/10.1139/f77-039

Krysanov EYu, Golubtsov AS (2014) Karyotypes of four fish species from the Nile and OmoTurkana basins in Ethiopia. Journal of Ichthyology 54: 889-892. https://doi.org/10.1134/ S0032945214100087

Lavoué S, Sullivan JP, Hopkins CD (2003) Phylogenetic utility of the first two introns of the S7 ribosomal protein gene in African electric fishes (Mormyroidea: Teleostei) and congruence with other molecular markers. Biological Journal of the Linnean Society 78: 273-292. https://doi.org/10.1046/j.1095-8312.2003.00170.x 
Lavoué S, Sullivan JP (2004) Simultaneous analysis of five molecular markers provides a wellsupported phylogenetic hypothesis for the living bony-tongue fishes (Osteoglossomorpha: Teleostei). Molecular Phylogenetics and Evolution 33: 171-185. https://doi.org/10.1016/j. ympev.2004.04.021

Levan A, Fredga K, Sandberg A (1964) Nomenclature for centromeric position on chromosomes. Hereditas 52: 201-220. https://doi.org/10.1111/j.1601-5223.1964.tb01953.x

Levin BA, Golubtsov AS (2018) New insights into the molecular phylogeny and taxonomy of mormyrids (Osteoglossiformes, Actinopterygii) in northern East Africa. Journal of Zoological Systematics and Evolutionary Research 56(1): 61-76. https://doi.org/10.1111/jzs.12186

Moritz T, El Dayem ZM, Abdallah MA, Neumann D (2019) New and rare records of fishes from the White Nile in the Republic of the Sudan. Cybium 43(2): 137-151.

Nakatani Y, Takeda H, Kohara Y, Morishita S (2007) Reconstruction of the vertebrate ancestral genome reveals dynamic genome reorganization in early vertebrates. Genome Research 17: 1254-1265. https://doi.org/10.1101/gr.6316407

Nelson JS, Grande T, Wilson MVH (2016) Fishes of the World (5 ${ }^{\text {th }}$ Edn.,). John Wiley \& Sons, Inc., Hoboken, New Jersey, 707 pp.

Ohno S, Muramoto J, Klein J, Atkin NB (1969) Diploid-tetraploid relationship in clupeoid and salmon fish. Chromozómes Today 2: 139-147.

Ozouf-Costaz C, Coutanceau J-P, Bonillo C, Belkadi L, Fermon Y, Agnèse J-F, Guidi-Rontani C, Paugy D (2015) First insights into karyotype evolution within the family Mormyridae. Cybium 39: 227-236.

Ráb P, Yano CF, Lavoué S, Jegede OI, Bertollo LAC, Ezaz T, Majtánová Z, de Oliveira EA, Marcelo B, Cioffi MB (2016) Karyotype and mapping of repetitive DNAs in the african butterfly fish Pantodon buchholzi, the sole species of the family Pantodontidae. Cytogenetic and Genome Research 149: 312-320. https://doi.org/10.1159/000450534

Sacerdot C, Louis A, Bon C, Berthelot C, Crollius HR (2018) Chromosome evolution at the origin of the ancestral vertebrate genome. Genome Biology 19: 1-166. https://doi. org/10.1186/s13059-018-1559-1

Sullivan JP, Lavoué S, Hopkins CD (2000) Molecular systematics of the African electric fishes (Mormyroidea: Teleostei) and a model for the evolution of their electric organs. Journal of Experimental Biology 203: 665-683.

Sullivan JP, Lavoué S, Hopkins CD (2016) Cryptomyrus: A new genus of Mormyridae (Teleostei, Osteoglossomorpha) with two new species from Gabon, West-Central Africa. ZooKeys 561: 117-150. https://doi.org/10.3897/zookeys.561.7137

Taverne L (1971) Note sur la systématique des poissons Mormyriformes. Le problème des genres Gnathonemus, Marcusenius, Hippopotamyrus, Cyphomyrus et les nouveaux genres Pollimyrus et Brienomyrus. Revue de Zoologie et de Botanique Africaines 84: 99-110.

Taverne L (1972) Ostéologie des genres Mormyrus Linné, Mormyrops Müller, Hyperopisus Gill, Myomyrus Boulenger, Stomatorhinus Boulenger et Gymnarchus Cuvier. Considérations générales sur la systématique des Poissons de l'ordre des Mormyriformes. Annales du Musée Royal de l'Afrique Centrale, Sciences Zoologiques 200: 1-194.

Uyeno T (1973) A comparative study of chromosomes in the teleostean fish order Osteoglossiformes. Japanese Journal of Ichthyology 20: 211-217. 